\title{
Antiviral mode of action of bovine dialyzable leukocyte extract against human immunodeficiency virus type 1 infection
}

\author{
Humberto H Lara*, Liliana Ixtepan-Turrent, Elsa N Garza-Treviño, Jose I Badillo-Almaraz and
}

Cristina Rodriguez-Padilla

\begin{abstract}
Background: Bovine dialyzable leukocyte extract (bDLE) is derived from immune leukocytes obtained from bovine spleen. DLE has demonstrated to reduce transcription of Human Immunodeficiency Virus Type 1 (HIV-1) and inactivate the nuclear factor kappa-light-chain-enhancer of activated B cells (NF- $\kappa \mathrm{B})$ signaling pathway. Therefore, we decided to clarify the mode of antiviral action of bDLE on the inhibition of HIV-1 infection through a panel of antiviral assays.

Results: The cytotoxicity, HIV-1 inhibition activity, residual infectivity of bDLE in HIV-1, time of addition experiments, fusion inhibition of bDLE for fusogenic cells and the duration of cell protection even after the removal of bDLE were all assessed in order to discover more about the mode of the antiviral action.

HIV-1 infectivity was inhibited by bDLE at doses that were not cytotoxic for HeLa-CD4-LTR- $\beta$-gal cells. Pretreatment of HIV-1 with bDLE did not decrease the infectivity of these viral particles. Cell-based fusion assays helped to determine if bDLE could inhibit fusion of Env cells against CD4 cells by membrane fusion and this cell-based fusion was inhibited only when CD4 cells were treated with bDLE. Infection was inhibited in $80 \%$ compared with the positive (without EDL) at all viral life cycle stages in the time of addition experiments when bDLE was added at different time points. Finally, a cell-protection assay against HIV-1 infection by bDLE was performed after treating host cells with bDLE for 30 minutes and then removing them from treatment. From 0 to 7 hours after the bDLE was completely removed from the extracellular compartment, HIV-1 was then added to the host cells. The bDLE was found to protect the cells from HIV-1 infection, an effect that was retained for several hours.

Conclusions: bDLE acted as an antiviral compound and prevented host cell infection by HIV-1 at all viral life cycle stages. These cell protection effects lingered for hours after the bDLE was removed. Interestingly, bDLE inhibited fusion of fusogenic cells by acting only on CD4 cells. bDLE had no virucidal effect, but could retain its antiviral effect on target cells after it was removed from the extracellular compartment, protecting the cells from infection for hours.

bDLE, which has no reported side effects or toxicity in clinical trials, should therefore be further studied to determine its potential use as a therapeutic agent in HIV-1 infection therapy, in combination with known antiretrovirals.
\end{abstract}

\section{Background}

The pandemic of Human Immunodeficiency Virus Type 1 (HIV-1) infection, the cause of Acquired Immunodeficiency Syndrome (AIDS), is a grave public health issue and ranks among the greatest infectious disease scourges in history [1]. There were more than 33.3 million people worldwide with HIV-1 infection or AIDS, according to the

\footnotetext{
*Correspondence: dr.lara.v@gmail.com

Laboratorio de Inmunología y Virología, Departamento de Microbiología e Inmunología, Universidad Autonoma de Nuevo Leon, Nuevo Leon, Mexico
}

latest estimates by the Joint United Nations Program on HIV/AIDS (UNAIDS) [2].

The use of highly active antiretroviral therapies has dramatically reduced morbidity and mortality among patients infected with HIV-1 [3,4]. However, the success of antiretroviral treatment is frequently restricted by the emergence of HIV-1 drug resistance [5]. Therefore, the search for new drugs to inhibit viral replication [6] or to restore the immune system in HIV-1 patients continues. Newly discovered naturally derived or chemically synthesized substances are continuously being evaluated as 
therapeutic drug candidates with antiviral activity. These potential drugs are eagerly awaited and may prove beneficial for the growing number of HIV-infected individuals who have developed resistance to the currently available antiretrovirals [7].

Dialyzable Leukocyte Extract (DLE) is derived from immune leukocytes and contains low molecular weight proteins $(<10,000 \mathrm{Da})$ [8]. DLE possess three chromatographic fractions $(\mathrm{Fa}, \mathrm{Fb}$ and $\mathrm{Fc})$, Fraction $\mathrm{Fb}$ inhibits viral production more than $80 \%$. Therefore, fractions $\mathrm{Fa}$ and Fc did not show inhibitory effect for any viral dose used [9].

This preparation is a modulator of the immune response that is able to transmit the ability to express delayed-type hypersensitivity (DTH) and cell mediated immunity (CMI) from sensitized donors to immune deficient recipients [10]. DLE also mediates effects on immune system functions, further influencing its response. These effects include cytokine modulation $[11,12]$, the activation of monocyte and macrophage chemotaxis [13] and natural killer activity enhancement [14]. The therapeutic and prophylactic applications have been the most important and interesting aspects of DLE [15], principally because there has been no reported side effects or toxicity in humans [16].

DLE has demonstrated to be effective in those diseases in which Cell-Mediated Immunity (CMI) plays a relevant role in protection against and control of the disease, such as viral infections ((herpes zoster [17], hepatitis B [18], intracellular bacterial diseases like tuberculosis [19] and leprosy [20], parasite infections, such as leishmaniasis [21] or cryptosporidiosis [22], and fungal infections (mucouscutaneous candidiasis [23]), as well as in primary immunodeficiencies (Wiskott Aldrich syndrome [24], Behçet's syndrome [25]), bronchial asthma [26], otitis media [27], uveitis [28]) and some types of cancer [29,30].

Previously we reported that bovine DLE (bDLE) was useful as an adjuvant in breast cancer patients undergoing chemotherapy, demonstrating protective effects against myelosuppression secondary to antitumoral drugs by improving cellular and humoral immunity, as well as in regulating the production of different cytokines involved in cellular proliferation $[16,29,30]$. Furthermore, in vitro assays demonstrated that bDLE affected the regulation of the expression of p53, bab-1, c-myc, bax, bcl-2 and bad mRNA [31,32]. Nowadays, the majority of the studies on DLE are limited to diseases that occur with chronic inflammation [33], like HIV-1 infection.

A main feature of HIV infection is the expression of several proinflammatory cytokines expressed as soluble factors or membrane-bound molecules that regulate both HIV replication and T cell apoptosis. Proinflammatory cytokines have key roles in the HIV lifecycle, especially at the level of transcription, by enhancing the ability of HIV to establish latent reservoirs on HIV infected patients. In addition, several HIV proteins, such as Nef, Tat, and Vpr hijack proinflammatory cytokine signaling, further underlining the potential importance of inflammation in HIV pathogenesis. Moreover, an in vivo chronic inflammatory state has been correlated to increased levels of viremia and accelerated disease progression [34]. DLE has been used to treat HIV-1 infected patients, either asymptomatic or at the AIDS phase, resulting in a partial immune reconstitution [35,36], a lower incidence of opportunistic infections [37], and clinically relevant improvement $[16,38]$.

Viruses have evolved to modulate the NF-kB pathway to enhance viral replication, improve host cell survival, and evade the immune response [39]. With HIV, viral and cellular membrane fusion activates NF- $\kappa \mathrm{B}$, a process that requires $\mathrm{CD} 4^{+} \mathrm{T}$ cells. HIV-1 contains regulatory regions in its long terminal repeat (LTR) implicated in the control of viral gene expression that contain three $\mathrm{Sp} 1$ core promoter binding sites and two NF- $\kappa \mathrm{B}$ core enhancer motifs [40] that are recognized by endogenous host cell transcription factors. These are important regulatory elements in the LTR that control expression of the promoter along with Tat, a viral transactivator protein necessary for HIV-1 replication [41].

Previous studies have reported DLE in vitro reduced HIV-1 transcription [42] by regulating activation of NF- $\kappa$ B and Sp1 transcription factors [42-44]. Other studies reported DLE induced the production of leukocytes and reduced TNF- $\alpha$ [44] and TFG- $\beta 1$ [45] secretion, which are cytokines that play a pivotal role in HIV-1 pathogenesis by up-regulating the transcription of HIV-1 and increasing the expression of HIV co-receptor CXCR4, respectively. Additionally, envelope glycoprotein gp120 can signal NF$\kappa \mathrm{B}$ by engaging the $\mathrm{CD}$ receptor in a pathway that involves p56 and activates NF- $\kappa$ B and HIV-1 LTR transcription [46]. HIV-1 gene expression and transcription is an essential step in the viral life cycle and is considered to be a possible target for the inhibition of HIV-1 replication [43]. The exact mechanism of action of bDLE is still unclear, however we focused on the bDLE mode of action against HIV-1 infection.

\section{Results \\ Cytotoxic effect}

The half cytotoxic concentration $\left(\mathrm{CC}_{50}\right)$ of bDLE when exposed to HeLa-CD4-LTR- $\beta$-gal cells was $3.41 \pm 0.1 \mathrm{IU}$ $(\mathrm{P}<0.0001)$ (Figure 1A).

\section{Range of antiviral activity}

bDLE was tested against an HIV-1 $1_{\text {IIIB }}$ isolate using indicator cells in which infection was quantified by a luciferase-based assay. The concentration of bDLE at which HIV-1 $1_{\text {IIIB }}$ infectivity was inhibited by $50 \%\left(\mathrm{IC}_{50}\right)$ was 
A

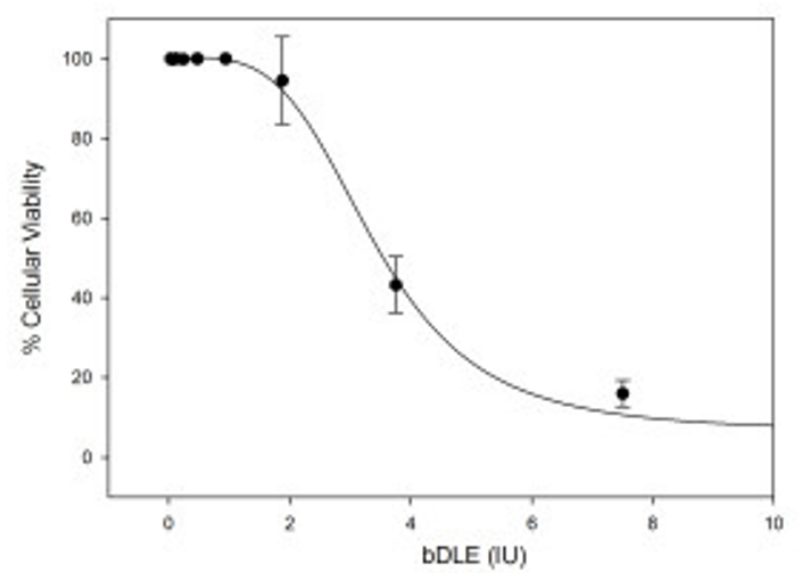

B

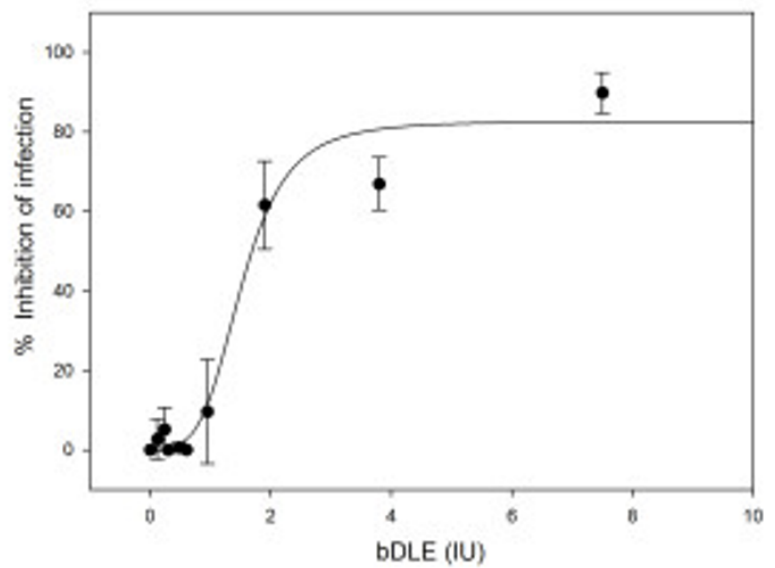

Figure 1 Cytotoxicity assessment of bDLE and HIV-1 inhibition activity. A) HeLa-CD4-LTR- $\beta$-gal cells $\left(5 \times 10^{4}\right.$ cells/well) and B) HIV- $1_{\text {IIB }}$ cellfree viruses (MOI 0.2-0.5) were challenged with two-fold serial dilutions of bDLE. Cell viability and $\beta$-gal activity were measured with a luciferasebased assay $24 \mathrm{~h}$ after nanosilver exposure. Percentage values are relative to the positive control (no compound treatment). The data represent the means \pm standard deviations from three separate experiments, each of which was carried out in duplicate.

found to be $1.53 \pm 0.1 \mathrm{IU}(\mathrm{P}<0.0001)$ (Figure 1B). In addition, bDLE inhibited HIV-1 $1_{\text {IIIB }}$ infectivity at doses that were not cytotoxic for HeLa-CD4-LTR- $\beta$-gal cells. The therapeutic index $\left(\mathrm{TI}=\mathrm{CC}_{50} / \mathrm{IC}_{50}\right)$ for bDLE in these cells was then calculated to be 2.23 . The therapeutic index reflects a compound's overall efficacy by relating cytotoxicity $\left(\mathrm{CC}_{50}\right)$ with effectiveness, measured as the ability to inhibit infection $\left(\mathrm{IC}_{50}\right)$, under the same assay conditions.

\section{Virucidal activity}

To determine if the bDLE might have effects on the virus itself, HIV-1 $1_{\text {IIIB }}$ isolates were treated with different concentrations of bDLE. After removal of bDLE, the residual infectivity of the cell-free viruses was quantified by a luciferase-based assay. As shown in Figure 2, bDLE pretreatment of HIV-1 $1_{\text {IIIB }}$ did not decrease the infectivity of the viral particles in a dose dependent manner.

\section{Inhibition of Env/CD4-mediated membrane fusion}

A cell-based fusion assay was used to mimic the gp120CD4-mediated fusion process of HIV-1 with bDLE. When bDLE was exposed first to the CD4 cells-Env cells mixture, fusion between both cells was blocked in a dose-dependent manner. Cell-based fusion was also inhibited when bDLE was applied only to CD4 cells for 30 minutes, followed by bDLE removal. However, when Env cells were first exposed to bDLE for 30 minutes, then removed and added to CD4 cells, fusion between both cells was not inhibited (Figure 3A). Known antiretroviral drugs, such as UC781 (NNRTI), were used as controls in this cell based fusion assay and did not inhibit cell fusion (Figure 3B). T-20 (Fusion Inhibitor), did inhibit cell fusion in all assays, however, except when exposed to CD4 cells for only 30 minutes and then removed, after which the cells were mixed (Figure 3C).

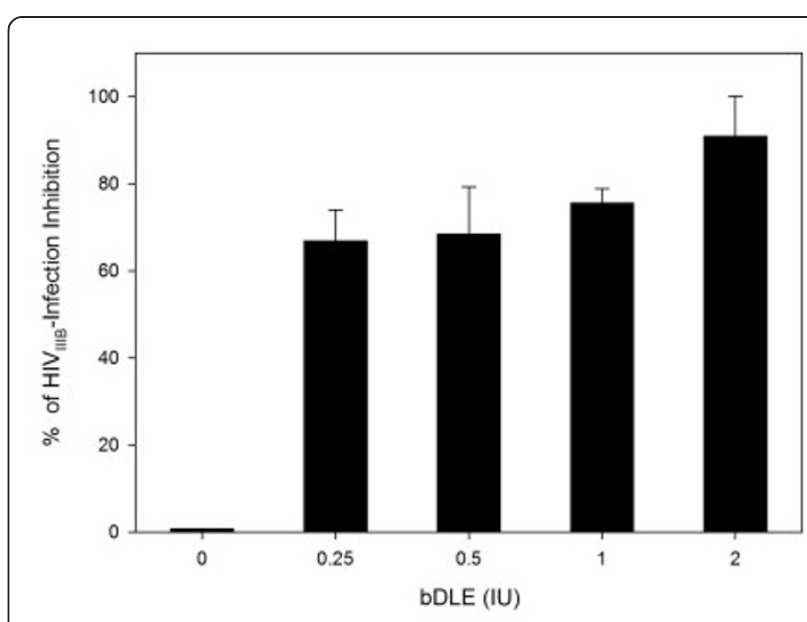

Figure 2 Residual activity in HIV-1 strains. HIV-1 ${ }_{\text {IIIB }}$ cell-free viruses were exposed to serial dilutions of bDLE for 5 minutes. The viruses were then ultracentrifuged, washed twice and added to HeLa-CD4-LTR- $\beta$-gal cells. After 24 hours, $\beta$-gal activity was measured. Percentage values are relative to the positive control (infected cells without bDLE treatment). The data represent the means \pm standard deviations from three separate experiments, each of which was carried out in duplicate. 


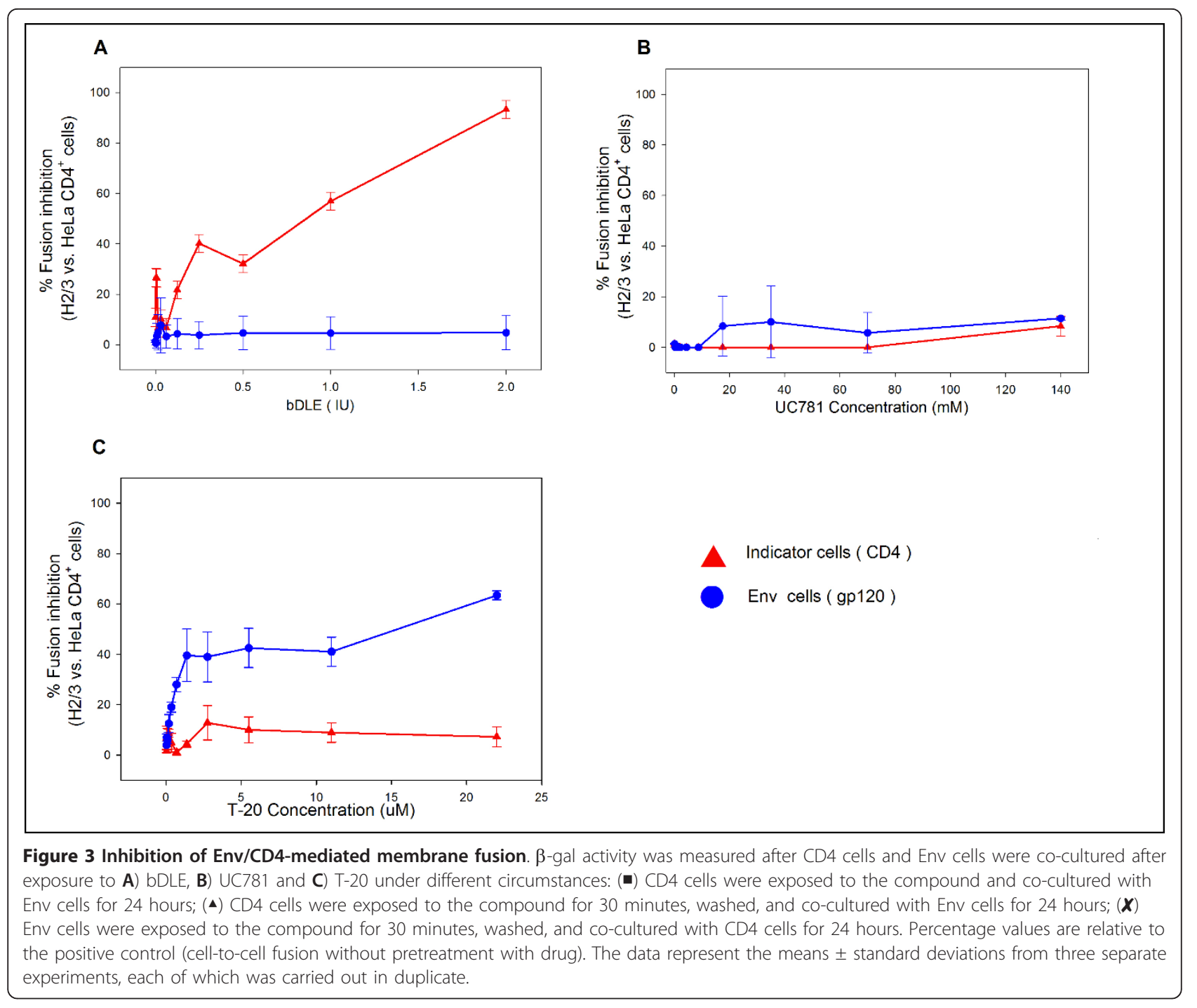

Time (Site) of Intervention

To further determine the antiviral target of bDLE, a timeof-addition experiment was performed using a single cycle infection assay. The time-of-addition experiment was used to determine the stage(s) of the viral life cycle that were blocked by bDLE. Several antiretroviral drugs were chosen as controls as they mark different stages of the viral cycle (i.e., fusion or entry, retrotranscription, protease activity, and integration into the genome). As seen in Figure 4(A-E), the antiviral activity of T-20, UC781, 118-D-24 and Amprenavir started to decline after the cycle stage that they targeted was passed. The fusion inhibitor's activity declined after $2 \mathrm{~h}$ (Figure 4B), the RT inhibitor after $8 \mathrm{~h}$ (Figure 4C), the integrase inhibitor after $18 \mathrm{~h}$ (Figure 4D) and the protease inhibitor after 15-18 h (Figure 4E). In contrast, bDLE retained its antiviral activity up to $48 \mathrm{~h}$ (Figure $4 \mathrm{~A}$ ) after the HIV inoculation, inhibiting HIV-1 infection in $80 \%$ of infected cells against the positive control.

\section{Cell protection assays}

HeLa-CD4-LTR- $\beta$-gal cells were pretreated with bDLE for 30 minutes, which was then removed from the extracellular compartment with three washes, and subsequently the HeLa-CD4-LTR- $\beta$-gal cells were exposed to HIV- $1_{\text {IIIB }}$ for different pretreatment times (1, 5, 7, 10, 24 and 48 hours). As shown in Figure 5, HIV-1 infection was inhibited, as host cells were protected even after 7 hours from the bDLE removal.

\section{Discussion}

Due to the DLE immunomodulatory properties discussed before, progression to AIDS in asymptomatic HIV-1 infected individuals treated with conventional 


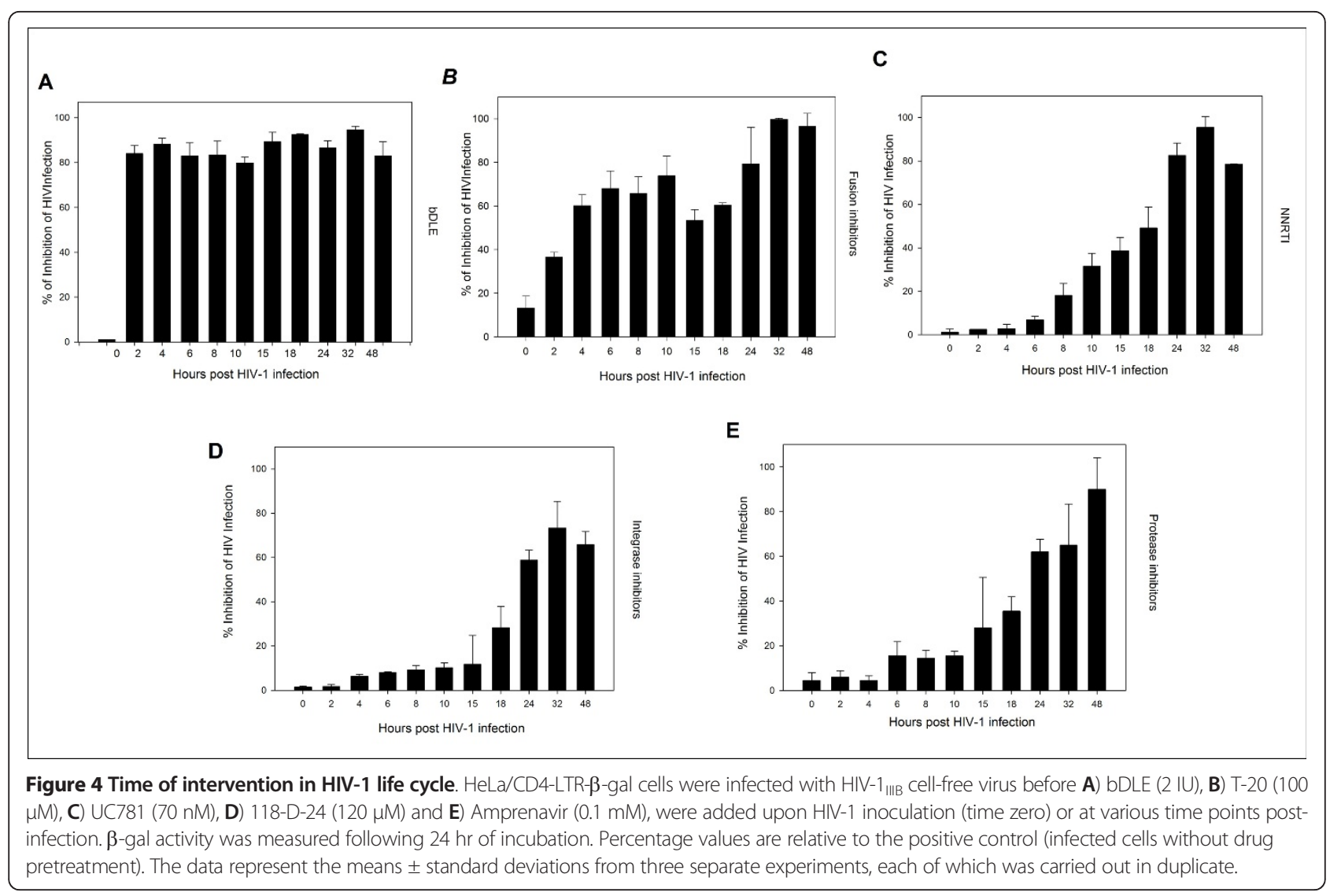

anti-retrovirals, has shown a retarded progression to AIDS under adjuvant treatment with dialyzable leukocyte extract (DLE), demonstrated by lower incidences of opportunistic infections and improved cellular immunity

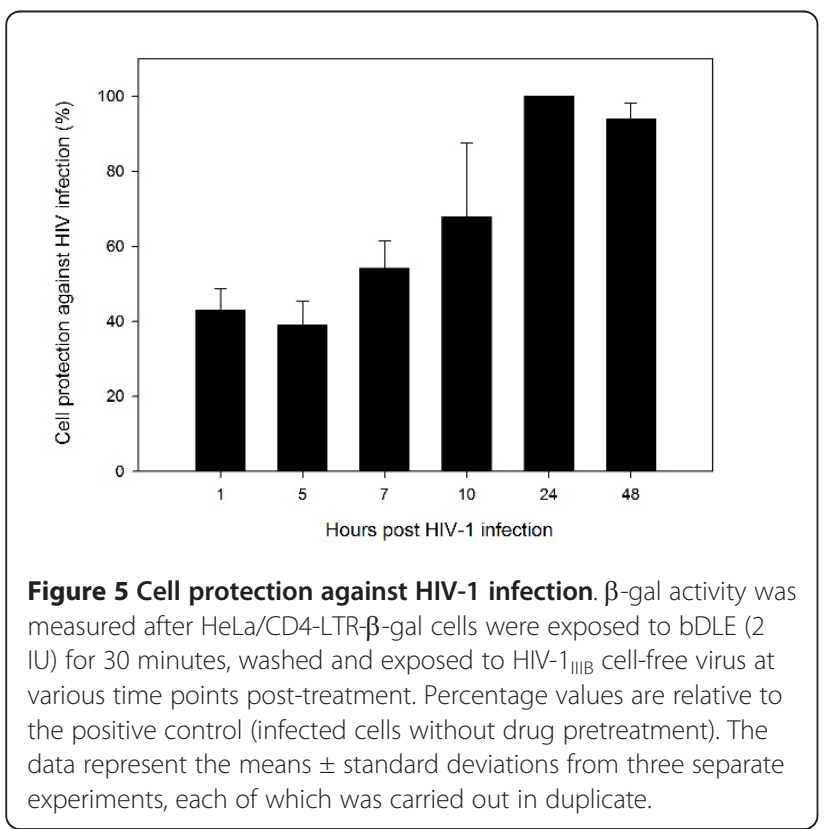

$[9,38,44]$. DLE simultaneously shows anti-HIV activity $[44,47,48]$, modulates different types of immune effectors (e.g., cytokines and transcription factors) $[11,47,49]$ and restores leukocyte subsets in treated patients $[16,29,35,37]$. All these properties make DLE a potential drug to be used in a therapeutic combination with antiretrovirals to improve immune and clinical responses.

Bovine dialyzable leukocyte extract (bDLE) is defined as the dialyzate of a heterogeneous mixture of low molecular weight substances released from disintegrated blood leukocytes or lymphoid tissue obtained from homogenized bovine spleen. Previous studies have shown inhibition of HIV-1 infection by suppression of the activity of essential transcription factors [42-44] and cytokines by DLE. The purpose of this study was to demonstrate the mechanism of antiviral action of bDLE in vitro in the inhibition of HIV-1 and the protection of host cells from infection.

First, we compared the half cytotoxic concentration of bDLE when exposed to HeLa-CD4-LTR- $\beta$-gal cells $\left(C_{50}=3.41 \mathrm{IU}\right)$ (Figure 1A) with the concentration of bDLE at which HIV-1 $1_{\text {IIIB }}$ infectivity was inhibited by $50 \%\left(\mathrm{IC}_{50}=1.33 \mathrm{IU}\right)$ (Figure $\left.1 \mathrm{~B}\right)$ [48]. Then, the therapeutic index was determined $(\mathrm{TI}=2.56)$ and used as an indicator of bDLE overall efficacy and safety. Despite 
the fact that TI was lower than expected $(<10)$, bDLE is a compound that has been used in clinical assays for more than fifty years without adverse reactions [10]. Better understanding of its inhibition mechanism can contribute to the development of new and improved anti-HIV-1 agents, which could be more efficient and have lower cytotoxicity. Furthermore, the residual infectivity $[50,51]$ of cell-free viruses after bDLE treatment showed no inhibitory activity (Figure 2), which suggests that bDLE does not act as a virucide on the viral membrane to inhibit infection. bDLE showed inhibition of fusogenic cell-cell interactions in a dose-dependent manner when bDLE was exposed to CD4 cells, bDLE was then removed and the CD4 cells were mixed with Env cells. However, after 30 minutes pretreatment of Env cells with bDLE and then transfer to CD4 cells, there was no inhibition of Env-CD4 cell fusion. This observation further supported our previous results that bDLE acted on CD4 expressing cells and not on the Env of the HIV-1 virus. Furthermore, when exposed to CD4 cells for only 30 minutes, which is the time required for conformational changes in gp120 after CD4 binding [52], bDLE again showed inhibition in a dose-dependent manner (Figure 3A). These data suggested that bDLE acted on CD4 cells to inhibit HIV-1 infection. Antiviral results reported by Fernandez-Ortega et al. [53,54] have also contributed to the knowledge of the molecular mechanisms responsible for the effectiveness of bDLE against HIV infection.

To further determine the antiviral target of bDLE, a time-of-addition experiment was used to define the stage (s) of the viral life cycle that are blocked by these compounds. These results were compared with several antiretroviral drugs as controls that marked different stages of the viral cycle [55-61] (Figure 4B-E). Our findings suggested that bDLE highly inhibited HIV-1 infection at all stages (Figure 4A), possibly due to viral Tat protein down-regulation (Tat activates $\beta$-galactosidase indicator gene expression in HeLa-CD4-LTR- $\beta$-gal cells). Inhibition of HIV-1 Tat activity correlates with down-regulation of $b c l-2$ [62], but the action of bDLE on $b c l-2$ has not yet been determined in HIV-1 studies. Previously, $b c l-2$ was found to be reduced in breast cancer cell lines when treated with bDLE [32]. Furthermore, DLE inactivated the NF- $\kappa \mathrm{B}$ signaling pathway by reducing the secretion of cytokines, such as IL- 1 and TNF- $\alpha$, which are effective inducers of NF- $\kappa \mathrm{B}$ activity [63]. In HIVinfected T cells, NF- $\kappa \mathrm{B}$-dependent transactivation is essential for HIV-LTR induction. Interestingly, even the function of HIV Tat in resting CD4 T lymphocytes depends on $\kappa \mathrm{B}$ responsive elements in the LTR [46]. Based on these interesting findings, it will be necessary to focus specifically on the transcriptional factors (NF- $\kappa$ B and SP1) and pro-apoptotic genes (bcl-2) in future research on bDLE as an antiviral against HIV-1 infection.

Lastly, bDLE was capable of rendering CD4 expressing cells resistant against HIV-1 infection by residual active virus for several hours [64]. Previous results indicated that, although pretreatment of cells (MT-4) with DLE for 3 hours had no effect, inhibition of HIV-1 production was observed when cells were pre-treated for a longer period of time (from 1 to 7 days), an effect that was characterized by the decline in TNF $\alpha$ and TGF $\beta 1$ gene expression and inhibition of transcriptional factors [9]. In our assays, after pretreatment of the HeLa-CD4-LTR- $\beta$-gal cells and bDLE removal prior to viral challenge, protection against infection lasted 7 hours after bDLE was removed from the extracellular compartment (Figure 5). These results indicated that bDLE could induce long-term viral inhibition through cell protection, as well as modulate cell susceptibility to viral infection in vitro, in agreement with previously reported data on DLE obtained from human donors by molecular methods [9].

\section{Conclusion}

The data presented here were novel in that they proved that bDLE acted by inhibiting HIV-1 infection through protection of the host target CD4 cells at noncytotoxic levels. This effect was found to be modulated through transcriptional factors (NF- $\kappa \mathrm{B}$ and SP1) necessary for HIV-1 replication. In addition, bDLE was discovered to act through all viral cycle stages to protect cells from HIV1 infection for hours without affecting the HIV membrane. Based on our results obtained above, bDLE should be further studied to determine its potential use as a therapeutic agent in HIV-1 infection, especially due to its longlasting cell protection against HIV-1 infection and lack of negative side effects.

\section{Methods}

\section{Reagents, cells and HIV-1 isolates}

The following reagents were obtained through the AIDS Research and Reference Reagent Program (NIH): HeLaCD4-LTR- $\beta$-gal cells from Dr. Michael Emerman; HL2/3 cells from Dr. Barbara K. Felber and Dr. George N. Pavlakis; HIV-1 ${ }_{\text {IIIB }}$, fusion inhibitor T-20, integrase inhibitor 118-D-24 and protease inhibitor Amprenavir from Dr. Suzanne Gartner, Dr. Mikulas Popovic and Dr. Robert Gallo. UC781, a no nucleoside reverse-transcriptase inhibitor (NNRTI), was kindly donated by Dr. Gadi Borkow. The bDLE used in our study was produced by the Laboratory of Immunology and Virology at the Universidad Autonoma de Nuevo Leon, Mexico, following a modified process described by Lawrence et al. [9]. The bDLE was lyophilized, tested for endogenous pyrogens using the Limulus amebocyte lysate assay (MP Biomedicals, 
Inc.), and determined to be free of bacterial contamination by culturing in media and in vivo mice inoculations. The bDLE obtained from $15 \times 10^{8}$ leukocytes was defined as one unit (1 Unit)[37].

\section{Cytotoxicity Assays}

A stock solution of bDLE was diluted two-fold diluted in growth medium and subsequently added into wells containing $5 \times 10^{4} \mathrm{HeLa}-\mathrm{CD} 4-\mathrm{LTR}-\beta$-gal cells. Microtiter plates were incubated at $37^{\circ} \mathrm{C}$ in a $5 \% \mathrm{CO}_{2}$ air humidified atmosphere for 24 hours. Assessments of cell viability were carried out using a CellTiter-Glo ${ }^{\circledR}$ Luminescent Cell Viability Assay (Promega). Cytotoxicity was evaluated based on the percentage cell survival relative to the result obtained in the absence of any compound.

\section{HIV-1 Infection Inhibition Assays}

Serial two-fold dilutions of bDLE were mixed with $10^{5}$ TCID $_{50}$ of HIV $-1_{\text {IIIB }}$ and added to the wells containing $5 \times$ $10^{4} \mathrm{HeLa}-\mathrm{CD} 4-\mathrm{LTR}-\beta$-gal cells with a multiplicity of infection (MOI) of $0.2-0.5$. HIV-1 infection was assessed after 24 hours of incubation by quantifying the activity of the $\beta$ galactosidase produced after infection with the Beta-Glo Assay System (Promega). The 50\% inhibitory concentration $\left(\mathrm{IC}_{50}\right)$ was defined according to the percentage of infection inhibited relative to the positive control.

\section{Virucidal Activity Assay}

Serial two-fold dilutions of bDLE were added to HIV-1 $1_{\text {IIIB }}$ (T tropic virus) and HIV-1 $1_{\mathrm{Ba}-\mathrm{L}}$ (M Tropic) cell-free virus. After incubation for $5 \mathrm{~min}$ at room temperature, the mixtures were centrifuged three times at $10,000 \mathrm{rpm}$, the supernatant fluids removed, and the pellets washed three times. The final pellets were resuspended in Dulbecco's Modified Eagle Medium (DMEM) and placed into 96-well plates with HeLa-CD4-LTR- $\beta$-gal cells. The cells were incubated in a $5 \% \mathrm{CO}_{2}$ humidified incubator at $37^{\circ} \mathrm{C}$ for $24 \mathrm{~h}$. Assessment of HIV-1 infection was made with the Beta-Glo Assay System. The percentage of residual infectivity after bDLE treatment was then calculated with respect to the positive control of untreated virus.

\section{Cell-based Fusion Assay}

HeLa-derived HL2/3 cells (Env cells), which express the HIV $-1_{\text {HXB2 }}$ Env, Tat, Gag, Rev, and Nef proteins, were co-cultured with HeLa-CD4-LTR- $\beta$-gal cells (CD4 cells) at a 1:1 cell density ratio $\left(5 \times 10^{4}\right.$ cells/well each $)$ for $24 \mathrm{~h}$ in the absence or presence of two-fold dilutions of bDLE, UC781, and T-20 in order to examine whether the compounds interfered with the binding process of HIV-1 Env and the CD4 receptor. Also, both HeLa-CD4-LTR- $\beta$-gal and HL2/3 cells were exposed to the aforementioned compounds for only 30 minutes and then washed twice to eliminate residual compound before co-cultivating with the other cell line. Upon fusion of both cell lines, the Tat protein from HL2/3 cells activated $\beta$-galactosidase $(\beta$-gal) indicator gene expression in HeLa-CD4LTR- $\beta$-gal cells [41]. $\beta$-gal activity was quantified with the Beta-Glo Assay System (Promega). The percentage of inhibition of HL2/3-HeLa CD4 cell fusion was calculated with respect to the positive control of untreated cells.

\section{Time of Addition Experiments}

HeLa-CD4-LTR- $\beta$-gal cells were infected with $10^{5}$ TCID $_{50}$ of HIV-1 $1_{\text {IIIB }}$ cell-free virus with a 0.2-0.5 MOI. bDLE (2 IU), T-20 (100 $\mu \mathrm{M}), \mathrm{UC781}(70 \mathrm{nM}), 118-\mathrm{D}-24(120 \mu \mathrm{M})$ and Amprenavir (0.1 mM) were then added upon HIV-1 inoculation (time zero) or at various time points postinoculation. The reference compounds were added at a concentration several times their $\mathrm{EC}_{50}$ for infectivity of HIV-1 $1_{\text {IIIB }}$. Infection inhibition was quantified after $24 \mathrm{~h}$ by measuring $\beta$-gal activity with the Beta-Glo Assay System.

\section{Cell Protection Assays}

HeLa-CD4-LTR- $\beta$-gal cells were incubated with bDLE (2 Units) for 30 minutes and subsequently washed with PBS three times. Then, the cells were exposed to $10^{5}$ TCID $_{50}$ of HIV-1 1 III cell-free virus with a 0.2-0.5 MOI for different times $(1,5,7,10,24$ and $48 \mathrm{~h})$. Infection inhibition was quantified after $24 \mathrm{~h}$ by measuring $\beta$-gal activity with the Beta-Glo Assay System.

\section{Statistical analysis}

Graphs were done with SigmaPlot 10.0 software and the values shown are means \pm standard deviations from three separate experiments, each of which was carried out in duplicate. Cytotoxicity and inhibition assessment graphs are linear regression curves done with SigmaPlot 10.0 software.

\section{Acknowledgements}

The following funding sources supported our experiments: the Programa de Apoyo a la Investigacion en Ciencia y Tecnologia (PAICyT) of the Universidad Autonoma de Nuevo Leon, Mexico, and the Consejo Nacional de Ciencia y Tecnologia (CONACYT) of Mexico.

\section{Authors' contributions}

All authors read and approved the final manuscript. HHL participated in the conception and experimental design of the in vitro HIV-1 manipulation and infection assays, in the analysis and interpretation of the data, and in the writing and revision of this report. LI-T participated in the analysis and interpretation the results. $\mathrm{HHL}$ and $\mathrm{LI}-\mathrm{T}$ made equal contributions to this study. EN-GT participated in the analysis and interpretation of the data and in writing and revising this report. SM-FT participated in the analysis and writing of the report. JIB participated in revising this report. CR-P participated in the experimental design of this research.

\section{Competing interests}

The authors declare that they have no competing interests.

Received: 24 July 2011 Accepted: 1 November 2011 Published: 1 November 2011 


\section{References}

1. Fauci AS: The AIDS epidemic-considerations for the 21st century. N Engl J Med 1999, 341:1046-1050.

2. Ganguly N: State of the Globe: The Immunological Quest for an HIV/AIDS Vaccine Continues. J Glob Infect Dis 2011, 3:209-210.

3. Palella FJ Jr, Delaney KM, Moorman AC, Loveless MO, Fuhrer J, Satten GA, et al: Declining morbidity and mortality among patients with advanced human immunodeficiency virus infection. HIV Outpatient Study Investigators. N Engl J Med 1998, 338:853-860

4. Sterne JA, May M, Costagliola D, de WF, Phillips AN, Harris R, et al: Timing of initiation of antiretroviral therapy in AIDS-free HIV-1-infected patients: a collaborative analysis of 18 HIV cohort studies. Lancet 2009 373:1352-1363.

5. Johnson VA, Brun-Vezinet F, Clotet B, Gunthard HF, Kuritzkes DR, Pillay D, et al: Update of the drug resistance mutations in HIV-1: December 2010. Top HIV Med 2010, 18:156-163.

6. Lara HH, Garza-Trevino EN, Ixtepan-Turrent L, Singh DK: Silver nanoparticles are broad-spectrum bactericidal and virucidal compounds. J Nanobiotechnology 2011, 9:30.

7. Caffrey M: HIV envelope: challenges and opportunities for development of entry inhibitors. Trends Microbiol 2011, 19:191-197.

8. Kirkpatrick $\mathrm{CH}$ : Transfer factors: identification of conserved sequences in transfer factor molecules. Mol Med 2000, 6:332-341.

9. Fernandez-Ortega C, Dubed M, Ruibal O, Vilarrubia OL, Menendez de San Pedro JC, Navea L, et al: Inhibition of in vitro HIV infection by dialysable leucocyte extracts. Biotherapy 1996, 9:33-40

10. Lawrence HS, Borkowsky W: Transfer factor-current status and future prospects. Biotherapy 1996, 9:1-5.

11. Franco-Molina MA, Mendoza-Gamboa E, Castillo-Leon L, Tamez-Guerra RS, Rodriguez-Padilla C: Bovine dialyzable leukocyte extract modulates the nitric oxide and pro-inflammatory cytokine production in lipopolysaccharide-stimulated murine peritoneal macrophages in vitro. $J$ Med Food 2005, 8:20-26.

12. Franco-Molina MA, Mendoza-Gamboa E, Castillo-Tello P, Isaza-Brando CE, Garcia ME, Castillo-Leon L, et al: Bovine dialyzable leukocyte extract modulates cytokines and nitric oxide production in lipopolysaccharidestimulated human blood cells. Cytotherapy 2007, 9:379-385.

13. Kirkpatrick CH, Rich RR, Smith TK: Effect of transfer factor on lymphocyte function in anergic patients. J Clin Invest 1972, 51:2948-2958.

14. Lang I, Nekam K, Gergely P, Petranyi G: Effect in vivo and in vitro treatment with dialyzable leukocyte extracts on human natural killer cell activity. Clin Immunol Immunopathol 1982, 25:139-144.

15. Fudenberg HH, Pizza G: Transfer factor 1993: new frontiers. Prog Drug Res 1994, 42:309-400.

16. Lara HH, Ixtepan Turrent L, Garza Treviño EN, Tamez-Guerra RS, RodriguezPadilla C, (Eds): Clinical and Immunological assessment in breast cancer patients receiving anticancer therapy and bovine dialyzable extract as an adjuvant. Experimental and Therapeutic Medicine 2010, 1:425-431.

17. Estrada-Parra S, Nagaya A, Serrano E, Rodriguez O, Santamaria V, Ondarza R, et al: Comparative study of transfer factor and acyclovir in the treatment of herpes zoster. Int J Immunopharmacol 1998, 20:521-535.

18. Mazzella G, Ronchi M, Villanova N, Mohamed AA, Pizza G, De VC, et al: Treatment of chronic $B$ virus hepatitis with specific transfer factor. Journal Exp Pathol 1987, 1:421-423.

19. Fabre RA, Perez TM, Aguilar LD, Rangel MJ, Estrada-Garcia I, HernandezPando $R$, et al: Transfer factors as immunotherapy and supplement of chemotherapy in experimental pulmonary tuberculosis. Clin Exp Immunol 2004, 136:215-223.

20. Hastings RC, Morales MJ, Shannon EJ, Jacobson RR: Preliminary results on the safety and efficacy of transfer factor in leprosy. Int J Lepr Other Mycobact Dis 1976, 44:275.

21. Delgado O, Romano EL, Belfort E, Pifano F, Scorza JV, Rojas Z: Dialyzable leukocyte extract therapy in immunodepressed patients with cutaneous leishmaniasis. Clin Immunol Immunopathol 1981, 19:351-359.

22. Louie E, Borkowsky W, Klesius PH, Haynes TB, Gordon S, Bonk S, et al: Treatment of cryptosporidiosis with oral bovine transfer factor. Clin Immunol Immunopathol 1987, 44:329-334.

23. Masi M, De VC, Baricordi OR: Transfer factor in chronic mucocutaneous candidiasis. Biotherapy 1996, 9:97-103.

24. Levin AS, Spitler LE, Stites DP, Fudenberg HH: Wiskott-Aldrich syndrome, a genetically determined cellular immunologic deficiency: clinical and laboratory responses to therapy with transfer factor. Proc Natl Acad Sci USA 1970, 67:821-828.

25. Wolf RE, Fudenberg HH, Welch TM, Spitler LE, Ziff M: Treatment of Bechcet's syndrome with transfer factor. JAMA 1977, 238:869-871.

26. Valdes Sanchez AF, Martin Rodriguez OL, Lastra AG: [Treatment of extrinsic bronchial asthma with transfer factor]. Rev Alerg Mex 1993, 40:124-131.

27. Kaminkova J, Lange CF: Transfer factor and repeated otitis media. Cell Immunol 1984, 89:259-264.

28. Abramson A, Khan A, Tate GW Jr, Martin RG, Hill NO: Immunocompetence and transfer factor therapy in uveitis. Br J Ophthalmol 1980, 64:332-338.

29. Franco-Molina MA, Mendoza-Gamboa E, Zapata-Benavides P, VeraGarcia ME, Castillo-Tello P, Garcia dIF, et al: IMMUNEPOTENT CRP (bovine dialyzable leukocyte extract) adjuvant immunotherapy: a phase I study in non-small cell lung cancer patients. Cytotherapy 2008, 10:490-496.

30. Whyte Rl, Schork MA, Sloan H, Orringer MB, Kirsh MM: Adjuvant treatment using transfer factor for bronchogenic carcinoma: long-term follow-up. Ann Thorac Surg 1992, 53:391-396.

31. Franco-Molina MA, Mendoza-Gamboa E, Miranda-Hernandez D, ZapataBenavides P, Castillo-Leon L, Isaza-Brando C, et al: In vitro effects of bovine dialyzable leukocyte extract (bDLE) in cancer cells. Cytotherapy 2006, 8:408-414

32. Mendoza-Gamboa E, Franco-Molina MA, Zapata-Benavides P, Castillo-Tello P, Vera-Garcia ME, Tamez-Guerra RS, et al: Bovine dialyzable leukocyte extract modulates AP-1 DNA-binding activity and nuclear transcription factor expression in MCF-7 breast cancer cells. Cytotherapy 2008, 10:212-219.

33. Franco-Molina MA, Mendoza-Gamboa E, Castillo-Leon L, Tamez-Guerra RS, Rodriguez-Padilla C: Bovine dialyzable leukocyte extract protects against LPS-induced, murine endotoxic shock. Int Immunopharmacol 2004 4:1577-1586

34. Roberts $L$, Passmore JA, Williamson C, Little F, Bebell LM, Mlisana $K$, et al: Plasma cytokine levels during acute HIV-1 infection predict HIV disease progression. AIDS 2010, 24:819-831

35. Gottlieb AA, Sizemore RC, Gottlieb MS, Kern CH: Rationale and clinical results of using leucocyte-derived immunosupportive therapies in HIV disease. Biotherapy 1996, 9:27-31.

36. Raise E, Guerra L, Viza D, Pizza G, De VC, Schiattone ML, et al: Preliminary results in HIV-1-infected patients treated with transfer factor (TF) and zidovudine (ZDV). Biotherapy 1996, 9:49-54.

37. McMeeking A, Borkowsky W, Klesius PH, Bonk S, Holzman RS, Lawrence HS: A controlled trial of bovine dialyzable leukocyte extract for cryptosporidiosis in patients with AIDS. J Infect Dis 1990, 161:108-112.

38. Pizza G, Chiodo F, Colangeli V, Gritti F, Raise E, Fudenberg HH, et al: Preliminary observations using HIV-specific transfer factor in AIDS. Biotherapy 1996, 9:41-47.

39. Li JC, Yim HC, Lau AS: Role of HIV-1 Tat in AIDS pathogenesis: its effects on cytokine dysregulation and contributions to the pathogenesis of opportunistic infection. AIDS 2010, 24:1609-1623.

40. Lim SP, Garzino-Demo A: The human immunodeficiency virus type 1 Tat protein up-regulates the promoter activity of the beta-chemokine monocyte chemoattractant protein 1 in the human astrocytoma cell line U-87 MG: role of SP-1, AP-1, and NF-kappaB consensus sites. J Virol 2000, 74:1632-1640.

41. Lalonde MS, Lobritz MA, Ratcliff A, Chamanian M, Athanassiou Z, Tyagi M, et al: Inhibition of both HIV-1 reverse transcription and gene expression by a cyclic peptide that binds the Tat-transactivating response element (TAR) RNA. PLoS Pathog 2011, 7:e1002038

42. Fernandez-Ortega C, Dubed M, Ramos Y, Navea L, Alvarez G, Lobaina L, et al: Non-induced leukocyte extract reduces HIV replication and TNF secretion. Biochem Biophys Res Commun 2004, 325:1075-1081.

43. Ojeda MO, Fernandez-Ortega C, Rosainz MJ: Dialyzable leukocyte extract suppresses the activity of essential transcription factors for HIV-1 gene expression in unstimulated MT-4 cells. Biochem Biophys Res Commun 2000, 273:1099-1103.

44. Ojeda MO, van't Veer C, Fernandez Ortega CB, Arana Rosainz MJ, Buurman WA: Dialyzable leukocyte extract differentially regulates the production of TNFalpha, IL- 6 , and IL- 8 in bacterial component-activated leukocytes and endothelial cells. Inflamm Res 2005, 54:74-81.

45. Elrefaei M, Burke CM, Baker CA, Jones NG, Bousheri S, Bangsberg DR, et al: HIV-specific TGF-beta-positive CD4+ T cells do not express regulatory 
surface markers and are regulated by CTLA-4. AIDS Res Hum Retroviruses 2010, 26:329-337.

46. Hiscott J, Kwon H, Genin P: Hostile takeovers: viral appropriation of the NF-kappaB pathway. J Clin Invest 2001, 107:143-151.

47. Carey JT, Lederman MM: Treatment of AIDS with transfer factor. JAMA 1987, 258:3515-3516.

48. Flory E, Weber CK, Chen P, Hoffmeyer A, Jassoy C, Rapp UR: Plasma membrane-targeted Raf kinase activates NF-kappaB and human immunodeficiency virus type 1 replication in T lymphocytes. J Virol 1998, 72:2788-2794.

49. Alvarez-Thull $L$, Kirkpatrick CH: Profiles of cytokine production in recipients of transfer factors. Biotherapy 1996, 9:55-59.

50. Lara HH, Ayala-Nunez NV, Ixtepan-Turrent L, Rodriguez-Padilla C: Mode of antiviral action of silver nanoparticles against HIV-1. J Nanobiotechnology 2010, 8:1.

51. Yang QE, Stephen AG, Adelsberger JW, Roberts PE, Zhu W, Currens MJ, et al: Discovery of small-molecule human immunodeficiency virus type 1 entry inhibitors that target the gp120-binding domain of CD4. J Virol 2005, 79:6122-6133.

52. Jones PL, Korte T, Blumenthal R: Conformational changes in cell surface HIV-1 envelope glycoproteins are triggered by cooperation between cell surface CD4 and co-receptors. J Biol Chem 1998, 273:404-409.

53. Demarchi F, d'Adda di FF, Falaschi A, Giacca M: Activation of transcription factor NF-kappaB by the Tat protein of human immunodeficiency virus type 1. J Virol 1996, 70:4427-4437.

54. Gaynor R: Cellular transcription factors involved in the regulation of HIV1 gene expression. AIDS 1992, 6:347-363.

55. Auwerx J, Stevens M, Van Rompay AR, Bird LE, Ren J, De CE, et al: The phenylmethylthiazolylthiourea nonnucleoside reverse transcriptase (RT) inhibitor MSK-076 selects for a resistance mutation in the active site of human immunodeficiency virus type 2 RT. J Virol 2004, 78:7427-7437.

56. Hombrouck A, Van RB, Michiels M, Noppe W, Christ F, Eneroth A, et al: Preclinical evaluation of $1 \mathrm{H}$-benzylindole derivatives as novel human immunodeficiency virus integrase strand transfer inhibitors. Antimicrob Agents Chemother 2008, 52:2861-2869.

57. Stevens M, Pannecouque C, De CE, Balzarini J: Novel human immunodeficiency virus (HIV) inhibitors that have a dual mode of antiHIV action. Antimicrob Agents Chemother 2003, 47:3109-3116.

58. Svarovskaia ES, Barr R, Zhang X, Pais GC, Marchand C, Pommier Y, et al: Azido-containing diketo acid derivatives inhibit human immunodeficiency virus type 1 integrase in vivo and influence the frequency of deletions at two-long-terminal-repeat-circle junctions. $J$ Virol 2004, 78:3210-3222.

59. Witvrouw M, Balzarini J, Pannecouque C, Jhaumeer-Laulloo S, Este JA, Schols D, et al: SRR-SB3, a disulfide-containing macrolide that inhibits a late stage of the replicative cycle of human immunodeficiency virus. Antimicrob Agents Chemother 1997, 41:262-268.

60. Witvrouw M, Fikkert V, Pluymers W, Matthews B, Mardel K, Schols D, et al: Polyanionic (i.e., polysulfonate) dendrimers can inhibit the replication of human immunodeficiency virus by interfering with both virus adsorption and later steps (reverse transcriptase/integrase) in the virus replicative cycle. Mol Pharmacol 2000, 58:1100-1108.

61. Zhang X, Pais GC, Svarovskaia ES, Marchand C, Johnson AA, Karki RG, et al: Azido-containing aryl beta-diketo acid HIV-1 integrase inhibitors. Bioorg Med Chem Lett 2003, 13:1215-1219.

62. Corallini A, Sampaolesi R, Possati L, Merlin M, Bagnarelli P, Piola C, et al: Inhibition of HIV-1 Tat activity correlates with down-regulation of bcl-2 and results in reduction of angiogenesis and oncogenicity. Virology 2002, 299:1-7.

63. Duh EJ, Maury WJ, Folks TM, Fauci AS, Rabson AB: Tumor necrosis factor alpha activates human immunodeficiency virus type 1 through induction of nuclear factor binding to the NF-kappa B sites in the long terminal repeat. Proc Natl Acad Sci USA 1989, 86:5974-5978.

64. Zussman A, Lara L, Lara HH, Bentwich Z, Borkow G: Blocking of cell-free and cell-associated HIV-1 transmission through human cervix organ culture with UC781. AIDS 2003, 17:653-661.

doi:10.1186/1756-0500-4-474

Cite this article as: Lara et al: Antiviral mode of action of bovine dialyzable leukocyte extract against human immunodeficiency virus type 1 infection. BMC Research Notes 2011 4:474.

\section{Submit your next manuscript to BioMed Central and take full advantage of:}

- Convenient online submission

- Thorough peer review

- No space constraints or color figure charges

- Immediate publication on acceptance

- Inclusion in PubMed, CAS, Scopus and Google Scholar

- Research which is freely available for redistribution 